\title{
Kinerja Alat Hydraulic Static Pile Driver (HSPD) Pada Proyek Perluasan Terminal Bandara Sultan Thaha Jambi
}

\author{
${ }^{1}$ Annisaa Dwiretnani, ${ }^{2}$ Indra Agustian Daulay \\ ${ }^{1}$ Dosen Teknik Sipil Universitas Batanghari \\ ${ }^{2}$ Mahasiswa Fakultas Teknik Sipil Universitas Batanghari \\ E-mail : annisaa.dwiretnani@gmail.com
}

\begin{abstract}
Abstrak
Salah satu alat yang umumnya dipakai pada proyek untuk bangunan tinggi adalah alat pancang untuk pengerjaan pondasi. Dengan keadaan proyek yang berada ditengah-tengah pemukiman penduduk lainnya, maka alat pancang yang sering digunakan dalam situasi ini adalah hydraulic static pile driver (HSPD). Kelebihan alat ini antara lain gangguan terhadap lingkungan dapat diminimalkan karena tidak menimbulkan getaran dan kebisingan. Konstruksi pondasi dalam (deep foundation) mempunyai struktur yang sangat kompleks dibandingkan dengan konstruksi pondasi dangkal (shallow foundation). Metode konstruksinya memiliki penampilan yang lebih rumit atau memiliki banyak keterkaitan dengan bagian-bagian lainnya. Salah satu jenis alat pancang yang sering digunakan adalah jenis hydraulic static pile driver (HSPD).
\end{abstract}

Kata Kunci : Efektifitas, Produktifitas, HSPD, Tiang Pancang, Analisa SWOT

\section{PENDAHULUAN}

Seiring dengan perkembangan proyek konstruksi, banyak alat-alat yang diciptakan dan dikembangkan untuk membantu dan mempermudah aktivitas dalam pengerjaan proyek konstruksi tersebut. Alat tidak lagi sepenuhnya menggunakan tenaga manusia tetapi manusia hanya menjadi bagian untuk proses pengoperasian alat tersebut.

Oleh sebab itu dalam pelaksanaanya pemilihan alat sangat perlu direncanakan dengan tepat dan cermat sesuai dengan keadaan proyek dan kemampuan pekerja. Pengoperasian alat yang salah dan penggunaan alat yang tidak tepat akan berpengaruh terhadap kinerja dari proyek tersebut. Demikian pula dengan ketersediaan tenaga kerja yang ahli dalam mengoperasikan alat tersebut.

Adapun tujuan dari penelitian ini adalah untuk mengetahui bagaimana efektifitas pemancangan dengan alat Hydraulic Static Pile Driver (HSPD) kapasitas 320 Ton, dan untuk mengetahui bagaimana efektifitas pemancangan dengan alat Hydraulic Static Pile Driver (HSPD) kapasitas 420 Ton.

\section{Landasan Teori \\ Pondasi}

Pondasi adalah bagian terendah dari suatu struktur bangunan yang berfungsi untuk meneruskan pembebanan konstruksi diatasnya kelapisan tanah atau batuan yang ada dibawahnya. Klasifikasi pondasi dibagi dua yaitu pondasi dangkal dan pondasi dalam. (Bowles, 1991) Jenis-jenis Pondasi :

1. Pondasi Dangkal

Pondasi dangkal adalah pondasi yang mendukung beban secara langsung. Pada umumnya suatu pondasi dikatakan pondasi dangkal jika $\mathrm{D} / \mathrm{B}<1$. Dan tanah pendukung pondasi terletak pada permukaan tanah atau kedalaman 2-3 m kebawah permukaan tanah. Jenisjenis pondasi dangkal sebagai berikut :

a. Pondasi telapak dan pondasi memanjang

Pondasi telapak adalah suatu pondasi yang mendukung bangunan secara langsung pada tanah pondasi, bila mana terdapat lapisan tanah yang cukup dan tebal dengan kualitas baik yang mampu mendukung bangunan itu pada permukaan tanah atau sedikit 
dibawah permukaan tanah.

Pondasi memanjang adalah pondasi yang digunakan untuk mendukung dinding memanjang atau digunakan mendukung sederetan kolom yang berjarak dekat, sehingga bila dipakai pondasi telapak sisi-sisinya akan terhimpit satu sama lain.

b. Pondasi Rakit (Raft Foundation atau Mat Foundation)

Pondasi rakit adalah pondasi yang digunakan untuk mendukung bangunan yang terletak pada tanah lunak atau digunakan bila susunan kolom-kolom jaraknya sedemikian dekat disemua arah, sehingga bila dipakai pondasi telapak sisi-sisinya akan berimpit satu sama lain.

c. Pondasi Sistem Cakar Ayam

Prinsip dasar dari pondasi ini adalah pondasi pelat penuh yang diperkuat dengan jangkar-jangkar dan pipa-pipa beton yang menyatu dengan pelat, pipa-pipa beton tersebut seolah-olah menggantung pada pelat. Kemampuan pondasi ini dapat mendukung beban bangunan yang berat seperti jembatan, konstruksi jalan, menara, landasan pesawat dan sebagainya.

2. Pondasi Dalam

Pondasi dalam didefinisikan sebagai pondasi yang meneruskan beban bangunan ketanah keras atau batu yang terletak relatif jauh dari permukaan. Pondasi dalam digunakan bila lapisan tanah didasar pondasi tidak mampu mendukung beban yang dilimpahkan dan terletak cukup dalam. Atau dengan pertimbangan adanya pengerusan dan galian dekat pondasi dikemudian hari. Umumnya dikatakan pondasi dalam apabila D/B > 4. Adapun jenis-jenis pondasi dalam adalah sebagai berikut :

a. Pondasi Sumuran (Pier Foundation)

Pondasi sumuran merupakan bentuk peralihan antara pondasi dangkal dan pondasi tiang, digunakan bila tanah dasar yang kuat terletak pada kedalaman yang relatif dalam.

b. Pondasi Kaison

Pondasi Kaison adalah suatu pondasi yang terletak pada lapisan pendukung, yang terbenam kedalam tanah karena beratnya sendiri dan dengan mengeluarkan tanah galian dari dasar bangunan bulat, yang terbuat dari beton bertulang.

c. Pondasi Tiang

Pondasi tiang adalah suatu struktur teknik yang meneruskan beban dari struktur bangunan atas melalui lapisan tanah lembek yang mampu mampat, atau melalui air ke dalam tanah yang lebih keras atau padat atau ke dalam batuan yang terletak lebih dalam.

\section{Pondasi Tiang Pancang}

Menurut Sosrodarsono \& Nakazawa, 2000, pondasi tiang pancang dapat dibedakan berdasarkan:

1. Kualitas Material

Dibedakan lagi menjadi:

a. Tiang Baja

1) Tiang pipa baja

2) Tiang dengan flens lebar (penampang $\mathrm{H}$ )

b. Tiang Beton

1) Tiang beton pra cetak :

a) Tiang beton bertulang pracetak

b) Tiang beton prategang pracetak

2) Tiang yang dicor ditempat :

a) Tiang alas 
b) Tiang beton Raymond

c) Dengan menggoyangkan semua tabung pelindung

d) Dengan membor tanah

e) Dengan pemutaran berlawanan arah

f) Dengan pondasi dalam

2. Teknik/Cara Pemancangan Tiang

Dibedakan menjadi:

a. Tiang pancang pracetak

1) Cara penumbukan

2) Cara penggetaran

3) Cara penanaman :

a) Cara pemboran sebelumnya

b) Cara pemboran inti

c) Cara pemancangan dengan tekanan

d) Cara pemancangan dengan menggunakan cara tiang yang dicor ditempat :

i. Tiang pipa baja

ii. Tiang dari balok dengan flens lebar

iii. Tiang beton bertulang dengan menggunakan gaya sentrifugal

iv. Tiang beton prategang dengan menggunakan gaya sentrifugal

v. Tiang komposit

b. Tiang yang dicor ditempat

1) Cara penetrasi-alas

2) Cara penggalian :

a) Penggalian dengan mesin

i. Cara osilasi seluruh tiang (BENOTO)

ii. Cara pemboran tanah

iii. Cara pemboran dalam arah berlawanan dengan arah jarum jam

iv. Cara pile in place (PIP)

v. Cara mixed in place (MIP)

b) Penggalian dengan tenaga manusia

i. Cara pondasi dalam

\section{Alat Pancang}

Ada beberapa jenis alat pemancang tiang yang umum digunakan dalam proyek konstruksi. Palu atau hammer yang berfungsi sebagai alat tiang pancang tersebut adalah: (Susy Fatena Rostiyanti, 2008)

a. Drop hammer

Drop hammer merupakan palu berat yang diletakkan pada ketinggian tertentu diatas tiang. Palu tersebut kemudian dilepaskan dan jatuh mengenai bagian atas tiang yang kepala tiang. Untuk menghindari tiang menjadi rusak akibat tumbukan ini, maka pada kepala tiang dipasangkan semacam topi atau cap sebagai penahan energi atau shock absorber. Biasanya cap dibuat dari kayu.

b. Diesel hammer

Diesel hammer terdiri dari dua jenis yaitu terbuka dan tertutup. Jenis alat yang bagian ujungnya terbuka mampu melakukan 40 sampai 55 blow per menit. Dalam pengoperasiannya, energi alat didapat dari berat ram yang menekan udara dalam silinder. Alat yang bagian ujungnya tertutup dapat menghasilkan blow 75 sampai 85 per menit.

c. Hydraulic hammer

Cara kerja hammer ini adalah berdasarkan perbedaan tekanan pada cairan hidrolis. Salah 
satu hammer tipe ini dimanfaatkan untuk memancangkan pondasi tiang baja $\mathrm{H}$ dan pondasi lempengan baja dengan cara dicengkeram, didorong dan ditarik. Dengan menggunakan alat pancang ini tekanan terhadap pondasi dapat mencapai 140 ton. Selain itu getaran dan polusi suara akibat pemakaian alat ini dapat dikurangi.

d. Vibratory Pile Driver

Alat ini sangat baik dimanfaatkan pada tanah lembab. Jika material dilokasi berupa pasir kering maka pekerjaan menjadi lebih sulit karena material tersebut tidak terpengaruh dengan adanya getaran yang dihasilkan oleh alat. Vibratory pile driver memiliki beberapa batang horizontal dengan beban eksentris. Pada saat pasangan batang berputar dengan arah yang berlawanan, berat yang disebabkan oleh beban eksentris menghasilkan getaran pada alat. Getaran yang dihasilkan menyebabkan material di sekitar pondasi yang terikat pada alat ikut bergetar.

e. Hydraulic Static Pile Driver (HSPD)

Hydraulic Static Pile Driver (HSPD) ini beroperasi menggunakan fluida hidrolic. Dimana sistem pemancangan tiang dengan cara menekan tiang masuk ke dalam tanah dengan menggunakan kekuatan sistem hidraulik yang mendapat reaksi pembebanan dari counterweight. Pemancangan dengan menggunakan hydraulic static pile driver tidak menimbulkan getaran dan suara bising. Kelebihannya adalah kita dapat mengetahui besarnya gaya tekan pada tiang dengan membaca langsung pada manometer.

Adapun spesifikasi teknis dari alat tersebut diatas adalah :

Tabel 1. Spesifikasi Alat HSPD Kapasitas 320 Ton

\begin{tabular}{|c|c|c|}
\hline No. & Uraian & \\
\hline 1. & Manufacture : Tianwei Engineering Machinery Co. Ltd, Changsha China & YZC320 \\
\hline 2. & Rate pilling pressure $(k N)$ & 3200 \\
\hline \multirow[t]{2}{*}{3.} & Pilling speed : Maximum $(\mathrm{m} / \mathrm{min})$ & 5,90 \\
\hline & Minimum $(\mathrm{m} / \mathrm{min})$ & 1,70 \\
\hline 4. & Pilling stroke $(m)$ & 1,80 \\
\hline \multirow[t]{2}{*}{5.} & Pace : Longitudinal (m) & 3,00 \\
\hline & Horizontal $(m)$ & 0,60 \\
\hline 6. & Rise stroke $(m)$ & 0,90 \\
\hline 7. & Max. square pile (mm) & 400 \\
\hline 8. & Max. circle pile (mm) & 550 \\
\hline 9. & Lifting weight (ton) & 12 \\
\hline 10. & Lifting piles length $(\mathrm{m})$ & 14 \\
\hline \multirow[t]{2}{*}{11.} & Power : Pilling $(k W)$ & 90 \\
\hline & Crane $(k W)$ & 30 \\
\hline 12. & Length of work & 12 \\
\hline 13. & Main dimension width of work $(\mathrm{m})$ & 3,30 \\
\hline 14. & Total weight (ton) & 328 \\
\hline
\end{tabular}

(Sumber: Hasil Penelitian di Lapangan, 2018)

\section{Hydraulic Static Pile Driver (HSPD)}

Salah satu jenis alat pancang yang sering digunakan terutama untuk daerah yang padat penduduk dan lokasi pekerjaannya ditengah kota adalah Hydraulic Static Pile Driver (HSPD). 


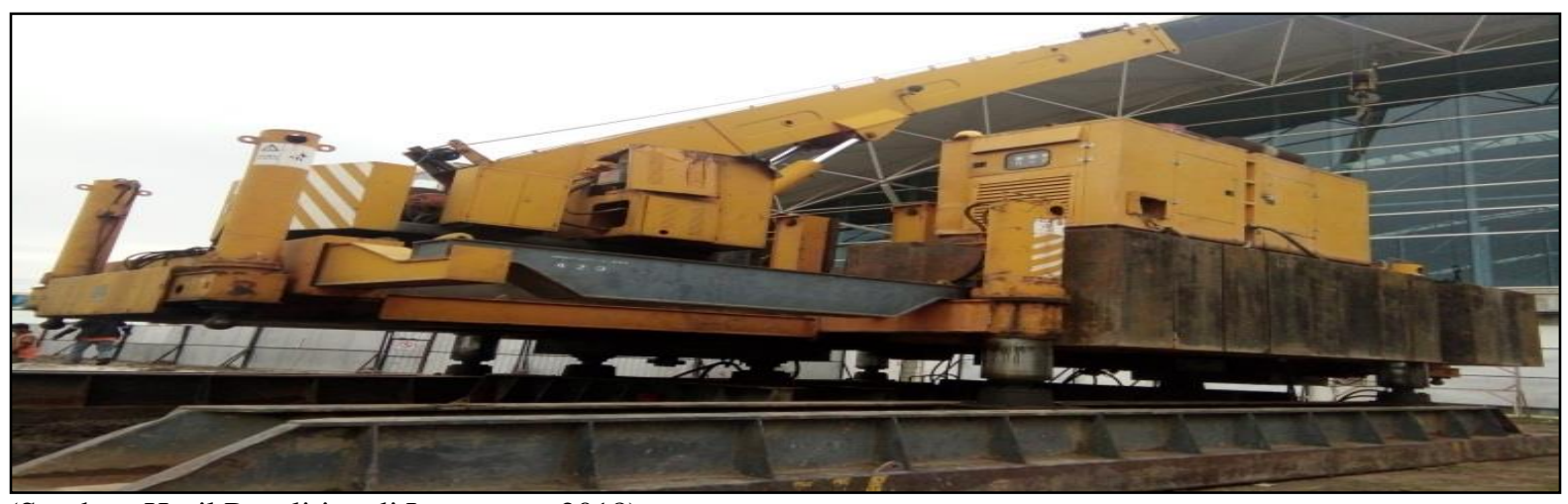

(Sumber: Hasil Penelitian di Lapangan, 2018)

Gambar 1. Alat Hydraulic Static Pile Driver (HSPD) Kapasitas 420 Ton

Komponen Alat Pancang Hydraulic Static Pile Driver (HSPD)

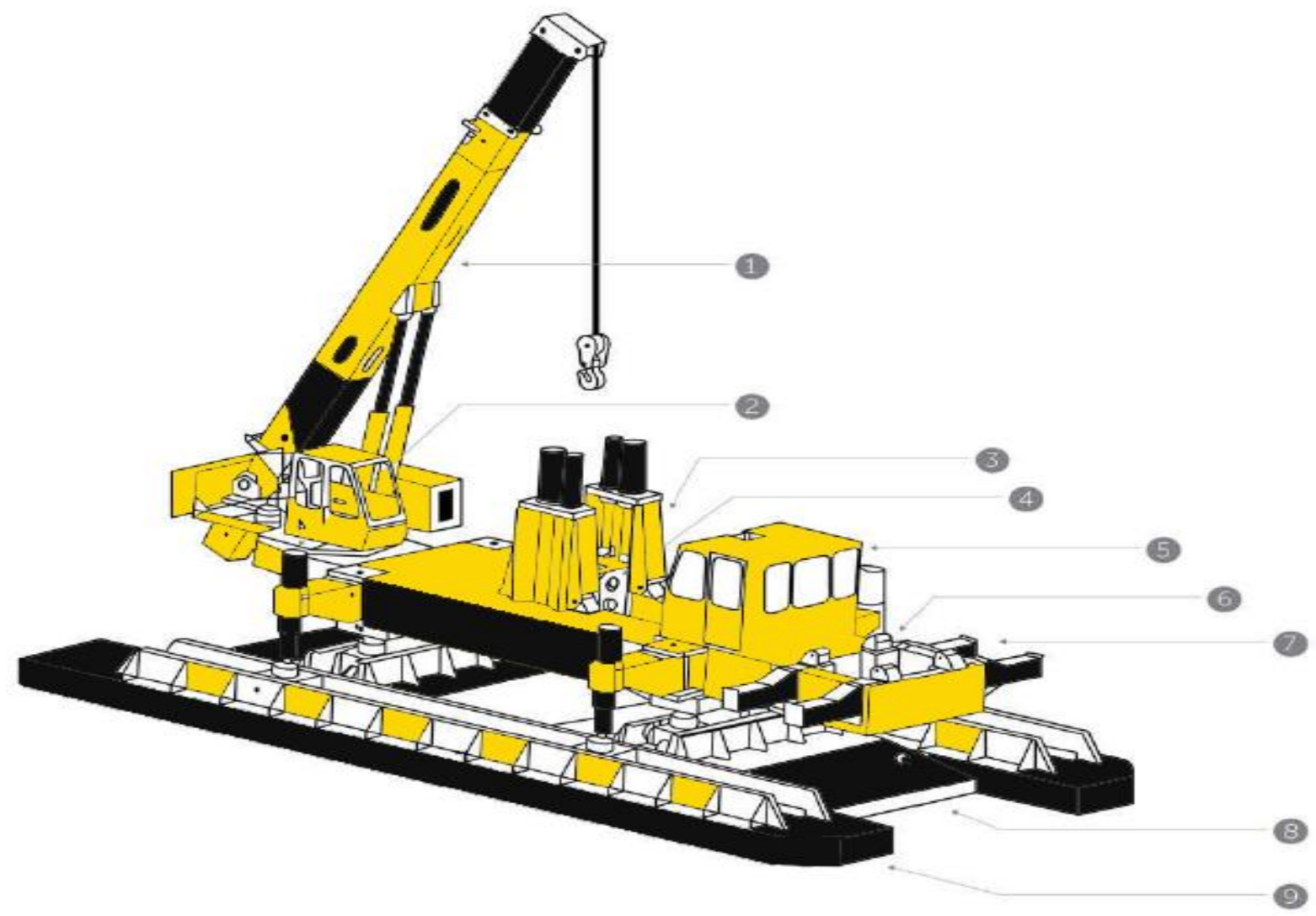

(Sumber : rumah material, 2018)

Gambar 2. Hydraulic Static Pile Driver (HSPD)

Uraian gambar :

1. Crane

2. Vertical Momen Mechanism

3. Pilling Platform

4. Pile Clamping Box

5. Main Cabin

6. Side Pilling Instalation Set

7. Assistant Cantilever

8. Cross Motion and Rotary Mechanism/Short Base 


\section{Longitudinal Motion and Rotary Mechanism/Long Base}

Beberapa ketentuan untuk dapat dilakukannya pelaksanaan pekerjaan pondasi tiang pancang sistem jack-in pile, yaitu sebagai berikut :

1. Lebar jalan menuju area proyek minimal $12 \mathrm{~m}$ dan dapat dilalui truk tronton untuk mengangkut material tiang pancang dengan beban sekitar 20 ton.

2. Pintu masuk ke area proyek dengan lebar minimal 4,5 $\mathrm{m}$ untuk jalan masuk alat pancang dan crane hidrolik serta truk.

3. Area diatas jalan masuk bebas dari kabel listrik/kabel telepon (minimal ada tinggi bebas 4,5 m yang dapat dilewati).

4. Untuk pekerjaan tiang pancang dalam bangunan, misalnya bangunan gudang, ketinggian bangunan minimal $9 \mathrm{~m}$ dan ada tempat dengan ketinggian $12 \mathrm{~m}$ untuk penyetelan alat pancang.

\section{Jenis dan Macam Kapasitas Alat HSPD}

Ada beberapa macam kapasitas alat HSPD yang sering digunakan, yaitu :

1. HSPD 120, Tekanan maksimum 120 ton, bisa untuk memancang tiang pancang kotak ukuran 20 x $20 \mathrm{~cm}$ sampai 35 x $35 \mathrm{~cm}$, dan spun pile ukuran diameter 30 sampai $35 \mathrm{~cm}$.

2. HSPD 150, Tekanan maksimum 150 ton, bisa untuk memancang tiang pancang kotak ukuran 20 x $20 \mathrm{~cm}$ sampai 35 x $35 \mathrm{~cm}$, dan spun pile ukuran diameter 30 sampai $40 \mathrm{~cm}$.

3. HSPD 240, Tekanan maksimum 240 ton, bisa untuk memancang tiang pancang kotak ukuran 20 x $20 \mathrm{~cm}$ sampai 45 x $45 \mathrm{~cm}$, dan spun pile ukuran diameter 30 sampai $50 \mathrm{~cm}$.

4. HSPD 320, Tekanan maksimum 320 ton, bisa untuk memancang tiang pancang kotak ukuran 20 × $20 \mathrm{~cm}$ sampai $50 \times 50 \mathrm{~cm}$, dan spun pile ukuran diameter 30 sampai $50 \mathrm{~cm}$.

5. HSPD 420, Tekanan maksimum 420 ton, bisa untuk memancang tiang pancang kotak ukuran 20 x $20 \mathrm{~cm}$ sampai $55 \times 55 \mathrm{~cm}$, dan spun pile ukuran diameter 30 sampai $60 \mathrm{~cm}$.

\section{Analisa SWOT}

Definisi analisis SWOT yang lainnya yaitu sebuah bentuk analisa situasi dan juga kondisi yang bersifat deskriptif (memberi suatu gambaran). Analisa ini menempatkan situasi dan juga kondisi sebagai sebagai faktor masukan, lalu kemudian dikelompokkan menurut kontribusinya masing-masing. Satu hal yang perlu diingat baik-baik oleh para pengguna analisa ini, bahwa analisa SWOT ini semata-mata sebagai suatu sebuah analisa yang ditujukan untuk menggambarkan situasi yang sedang dihadapi, dan bukan sebuah alat analisa ajaib yang mampu memberikan jalan keluar yang bagi permasalahan yang sedang dihadapi. SWOT adalah singkatan dari (Wikipedia, 2015):

a. $\mathrm{S}=$ Strength (kekuatan), yaitu analisis kekuatan, situasi ataupun kondisi yang merupakan kekuatan dari suatu organisasi atau perusahaan pada saat ini.

b. $\mathrm{W}=$ Weaknesses (kelemahan), yaitu analisis kelemahan, situasi ataupun kondisi yang merupakan kelemahan dari suatu organisasi atau perusahaan pada saat ini.

c. $\mathrm{O}=$ Opportunities (peluang), yaitu analisis peluang, situasi atau kondisi yang merupakan peluang diluar suatu organisasi atau perusahaan dan memberikan peluang berkembang bagi organisasi dimasa depan.

d. $\mathrm{T}=$ Threats (hambatan), yaitu analisis ancaman, cara menganalisis tantangan atau ancaman yang harus dihadapi oleh suatu perusahaan ataupun organisasi untuk menghadapi berbagai macam faktor lingkungan yang tidak menguntungkan pada suatu perusahaan atau organisasi yang menyebabkan kemunduran.

Metode analisis SWOT bisa dianggap sebagai metode analisis yang paling dasar, yang bermanfaat untuk melihat suatu topik ataupun suatu permasalahan dari 4 empat sisi yang berbeda. Hasil dari analisa biasanya berupa arahan ataupun rekomendasi untuk 
mempertahankan kekuatan dan untuk menambah keuntungan dari segi peluang yang ada, sambil mengurangi kekurangan dan juga menghindari ancaman. Jika digunakan dengan benar, analisis ini akan membantu untuk melihat sisi-sisi yang terlupakan atau tidak terlihat selama ini.

\section{METODE}

\section{Tahapan proses pemancangan tiang pancang}

1. Pengikatan tiang pancang bawah

2. Pengangkatan tiang pancang bawah

3. Pemindahan tiang pancang bawah

4. Pemasukan tiang pancang bawah

5. Penyipatan/penjepitan tiang pancang bawah

6. Penekanan tiang pancang bawah

7. Pengambilan tiang pancang tengah

8. Pengikatan tiang pancang tengah

9. Pengangkatan tiang pancang tengah

10. Pemindahan tiang pancang tengah

11. Pemasukan tiang pancang tengah

12. Penyipatan/penjepitan tiang pancang tengah

13. Penekanan tiang pancang tengah

14. Pengelasan $\&$ pengecatan sambungan tiang pancang bawah dan tengah

15. Penekanan lanjutan tiang pancang tengah

16. Pengambilan tiang pancang atas

17. Pengikatan tiang pancang atas

18. Pengangkatan tiang pancang atas

19. Pemindahan tiang pancang atas

20. Pemasukan tiang pancang atas

21. Penyipatan/penjepitan tiang pancang atas

22. Penekanan tiang pancang atas

23. Pengelasan $\&$ pengecatan sambungan tiang pancang tengah dan atas

24. Penekanan lanjutan tiang pancang atas

25. Pengambilan tiang pancang bantu dorong (ruyung/dolly)

26. Pengikatan tiang pancang bantu dorong (ruyung/dolly)

27. Pengangkatan tiang pancang bantu dorong (ruyung/dolly)

28. Pemindahan tiang pancang bantu dorong (ruyung/dolly)

29. Pemasukan tiang pancang bantu dorong (ruyung/dolly)

30. Penyipatan/penjepitan tiang pancang bantu dorong (ruyung/dolly)

31. Penekanan tiang pancang bantu dorong (ruyung/dolly)

32. Pengangkatan tiang pancang bantu dorong (ruyung/dolly)

33. Pemotongan sisa tiang pancang atas

Catatan : Tiang pancang bantu dorong (ruyung/dolly) hanya digunakan sebagai alat bantu mendorong tiang pancang atas pada saat menekan tiang pancang atas, sehingga tiang ruyung/dolly ini tidak disambung/dilas dengan tiang pancang sebelumnya. Tiang ruyung/dolly bentuk dan dimensinya sama dengan tiang spun pile yang digunakan pada pelaksanaan pemancangan.

\section{Lokasi dan Data Sampel Penelitian}

Penelitian dilakukan dengan pengamatan secara langsung di Proyek Perluasan Terminal Bandara Sultan Thaha Jambi dari bulan Januari 2018 sampai dengan Mei 2018 untuk 
pelaksanaan pekerjaan pemancangan tiang pondasi, dengan pengambilan/pencatatan data terhadap durasi aktivitas pelaksanaan alat pancang.

Data sampel yang diamati selama penelitian adalah:

1. Untuk area kerja unit 1 dengan menggunakan alat HSPD kapasitas 320 Ton, dimana total jumlah titik pancang yang terlaksana dilapangan mencapai 157 titik pancang.

2. Untuk area kerja unit 2 dengan menggunakan alat HSPD kapasitas 420 Ton, dimana total jumlah titik pancang yang terlaksana dilapangan mencapai 182 titik pancang.

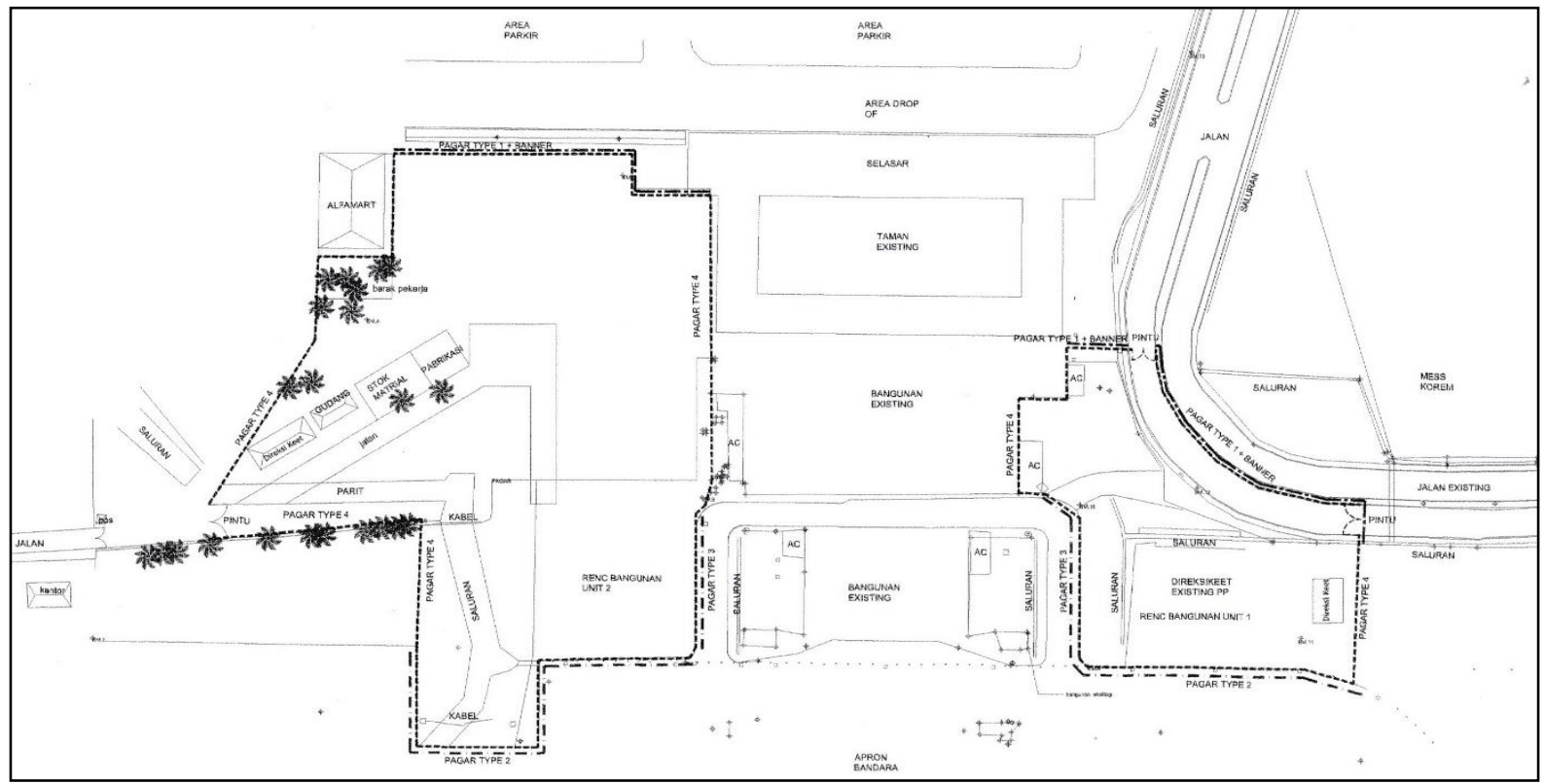

(Sumber : Hasil Penelitian di Lapangan, 2018)

Gambar 3. Siteplan Lokasi Pekerjaan

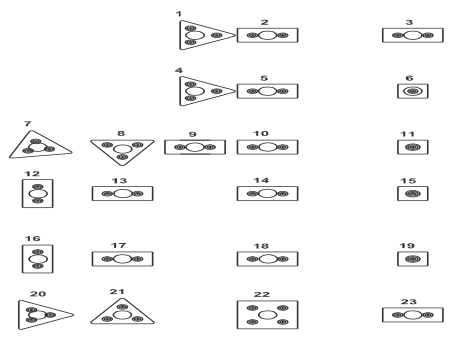

\begin{tabular}{|c|c|c|c|c|c|c|c|c|}
\hline 25 & & $\frac{28}{0}=$ & 登. & ${ }_{-0.0}^{28}$ & $\underbrace{20}_{\infty}$ & ${ }_{\infty}^{30}$ & 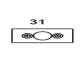 & \\
\hline 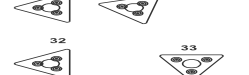 & & .ิ. & $\infty_{\infty}^{35}$ & 36 & 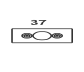 & $=$ & 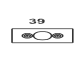 & \\
\hline 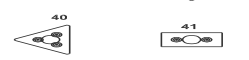 & & 42 & S. & $n$ & .5. & . & 4 & \\
\hline$=8=$ & $\begin{array}{l}51 \\
8 \\
8\end{array}$ & $\begin{array}{l}50 \\
50 \\
500 \\
520 \\
500 \\
500 \\
500\end{array}$ & $\underset{5}{53}$ & $\underbrace{54}_{50}$ & $\overbrace{5 \infty}^{55}$ & $\underset{5 \infty}{58}$ & 5 & 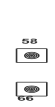 \\
\hline
\end{tabular}

(Sumber : Hasil Penelitian di Lapangan, 2018)

Gambar 4. Denah Titik Lokasi Pancang Unit 1 Proyek Perluasan Terminal Bandara Sultan Thaha Jambi 


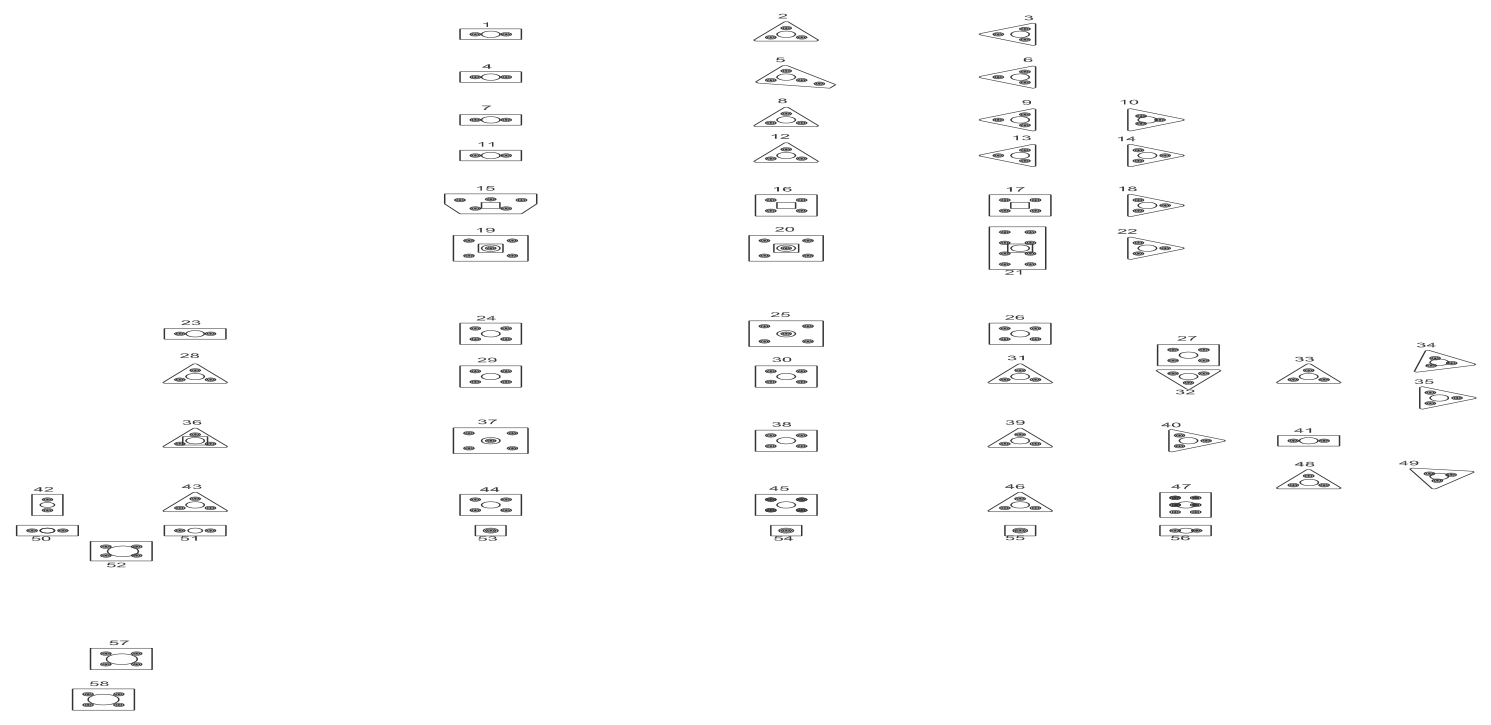

(Sumber : Hasil Penelitian di Lapangan, 2018)

Gambar 5. Denah Titik Lokasi Pancang Unit 2 Proyek Perluasan Terminal Bandara Sultan Thaha Jambi

\section{Analisa Data}

Analisa yang digunakan untuk menghitung produktifitas alat HSPD yaitu :

1. Analisa Rata-rata

Analisis Mean digunakan untuk menentukan rata-rata durasi suatu aktivitas dalam proses pemancangan suatu proyek. Dalam sub-bab ini akan diperlihatkan rata-rata durasi tiap aktivitas dalam proses pemancangan pada proyek Perluasan Terminal Bandara Sultan Thaha Jambi. Untuk mencari mean dapat digunakan formula sebagai berikut :

$$
\overline{\mathrm{X}}=\frac{\sum_{\mathrm{i}=1}^{\mathrm{N}} \mathrm{Xi}}{\mathrm{N}}
$$

Keterangan :

$$
\bar{X}=\text { rata-rata }(\text { mean }) \quad \mathrm{X}_{\mathrm{i}}=\text { data ke-i (urutan data ) } \quad \mathrm{N}=\text { jumlah data }
$$

2. Analisa Produktifitas

Analisis ini digunakan untuk mengetahui produktifitas alat pancang jack-in pile tipe Hydraulic Static Pile Driver (HSPD) ditinjau dari panjang tiang berdasarkan durasi/lamanya pemancangan. Untuk mengetahui produktifitas alat HSPD digunakan rumus :

$$
\text { Produktifitas }(\mathrm{Q})=\frac{\text { Kedalaman }(\mathrm{q})}{\text { Waktu Pancang }(\mathrm{CT})} \times \text { Efisiensi Kerja Alat }
$$

\section{HASIL}

\section{Perhitungan Produktifitas Alat HSPD}

Dalam menghitung produktifitas alat berat ada nilai efisiensi kerja alat yang menjadi faktor pendukung, dimana nilai efisiensi kerja alat dapat dilihat pada tabel 2. Dan nilai yang digunakan dalam menghitung produktifitas ini adalah $\mathbf{0 , 7 5}$ dengan kondisi operasi alat dan pemeliharaan mesin adalah BAIK. 
Tabel 2. Nilai Efisiensi Kerja Alat

\begin{tabular}{lccccc}
\hline \multicolumn{1}{c}{ Kondisi Operasi Alat } & \multicolumn{2}{c}{ Pemeliharaan Mesin } & \\
& Baik Sekali & Baik & Sedang & Buruk & Buruk Sekali \\
\hline Baik Sekali & 0,83 & 0,83 & 0,76 & 0,7 & 0,63 \\
Baik & 0,7 & 0,75 & 0,71 & 0,65 & 0,6 \\
Sedang & 0,72 & 0,69 & 0,65 & 0,6 & 0,54 \\
Buruk & 0,63 & 0,61 & 0,57 & 0,52 & 0,45 \\
Buruk Sekali & 0,52 & 0,5 & 0,47 & 0,42 & 0,32 \\
\hline
\end{tabular}

(Sumber : Wilopo, 2009)

a. Berdasarkan Waktu Pemancangan

Dari data durasi pemancangan setiap lokasi titik tiang pancang yang menjadi sampel penelitian, selanjutnya dihitung nilai produktifitas alat tersebut.

Titik Pancang G3 No.22

Kedalaman Tiang Pancang $\quad=26,50 \mathrm{~m}$

Waktu Pemancangan $\quad=85$ menit

Nilai Efisiensi Kerja Alat $\quad=0,75$

Dengan rumus diatas diperoleh :

$$
\mathrm{Q}=\frac{26,50 \text { meter }}{85 \text { menit }} \times 0,75=0,23 \mathrm{~m} / \text { menit }
$$

Titik Pancang G3 No.23

Kedalaman Tiang Pancang $\quad=27,00 \mathrm{~m}$

Waktu Pemancangan $\quad=96$ menit

Nilai Efisiensi Kerja Alat $\quad=0,75$

Dengan rumus diatas diperoleh :

$$
Q=\frac{27,00 \text { meter }}{96 \text { menit }} \times 0,75=0,21 \mathrm{~m} / \text { menit }
$$

Titik Pancang A'1 No.131

Kedalaman Tiang Pancang $\quad=25,50 \mathrm{~m}$

Waktu Pemancangan $\quad=76$ menit

Nilai Efisiensi Kerja Alat $\quad=0,75$

Dengan rumus diatas diperoleh :

$$
Q=\frac{25,50 \text { meter }}{76 \text { menit }} \times 0,75=0,25 \mathrm{~m} / \text { menit }
$$

b. Perhitungan Produktifitas Alat HSPD 420 Ton Berdasarkan Waktu Pemancangan

Titik Pancang J16 No.04

Kedalaman Tiang Pancang $\quad=26,00 \mathrm{~m}$

Waktu Pemancangan $\quad=67$ menit

Nilai Efisiensi Kerja Alat $\quad=0,75$

Dengan rumus diatas diperoleh :

$$
\mathrm{Q}=\frac{26,00 \text { meter }}{67 \text { menit }} \times 0,75=0,29 \mathrm{~m} / \text { menit }
$$

Titik Pancang B16 No.115

Kedalaman Tiang Pancang $\quad=27,00 \mathrm{~m}$

Waktu Pemancangan $\quad=66$ menit

Nilai Efisiensi Kerja Alat $\quad=0,75$ 
Dengan rumus diatas diperoleh :

$$
Q=\frac{27,00 \text { meter }}{66 \text { menit }} \times 0,75=0,31 \mathrm{~m} / \text { menit }
$$

Titik Pancang B16 No.117

Kedalaman Tiang Pancang $\quad=27,50 \mathrm{~m}$

Waktu Pemancangan $\quad=62$ menit

Nilai Efisiensi Kerja Alat $\quad=0,75$

Dengan rumus diatas diperoleh :

$$
Q=\frac{27,50 \text { meter }}{62 \text { menit }} \times 0,75=0,33 \mathrm{~m} / \text { menit }
$$

c. Berdasarkan Biaya Pemancangan

Untuk menghitung produktifitas alat HSPD berdasarkan biaya, ada beberapa komponen biaya yang dikeluarkan selama pelaksanaan pekerjaan pemancangan. Komponen biayabiaya tersebut adalah :

1) Biaya Sewa Alat HSPD

Biaya sewa alat HSPD termasuk kedalam :

a) Biaya Mobilisasi dan Demobilisasi

Biaya mobilisasi dan demobilisasi alat HSPD dari data yang diperoleh adalah :

i. Alat HSPD kapasitas 320 ton $=$ Rp.350.000.000,-

ii. Alat HSPD kapasitas 420 ton $=$ Rp.400.000.000,-

b) Biaya Pemancangan Tiang Pancang

Biaya pemancangan tiang pancang dari data yang diperoleh Penulis adalah Rp.100.000,-/m x 10.170,00 $\mathrm{m}^{1}=$ Rp. 1.017.000.000,00

c) Biaya Penyambungan (Handling Spun Pile)

Biaya handling tiang pancang dari data yang diperoleh Penulis adalah Rp.195.000,$/ \mathrm{m}^{1} \times 10.170,00 \mathrm{~m}^{1}=$ Rp. 1.983.150.000,00

d) Biaya Pengelasan dan Pemotongan Tiang Pancang (joint dan welding)

Biaya penyambungan dan pengelasan tiang pancang dari data yang diperoleh Penulis adalah :

i. Biaya Penyambungan/Pengelasan $=$ Rp.390.000,-/joint $\times 2 \times 339$ titik $=$ Rp. 264.420.000,00

ii. Biaya Pemotongan Tiang Pancang $=$ Rp.20.000,- $x 339$ titik $=$ Rp. 6.780.000,00

2) Biaya Bahan Bakar Minyak (BBM)

Biaya bahan bakar (BBM) yang dikeluarkan untuk kedua alat HSPD adalah :

a) Alat HSPD kapasitas 320 ton

Bahan Bakar Minyak (BBM) yang dikeluarkan untuk 38 hari kerja, dimana jumlah BBM setiap harinya adalah 180 liter.

Biaya BBM = 38 hari $x 180$ liter $x$ Rp.13.000,-/liter = Rp. 88.920.000,00

b) Alat HSPD kapasitas 420 ton

Bahan Bakar Minyak (BBM) yang dikeluarkan untuk 49 hari kerja, dimana jumlah BBM setiap harinya adalah 200 liter.

Biaya $\mathrm{BBM}=49$ hari $\mathrm{x} 200$ liter $\times$ Rp.13.000,-/liter $=$ Rp. 127.000.000,00

\section{SIMPULAN}

Dari hasil perhitungan dapat disimpulkan :

1. Berdasarkan waktu pemancangan titik lokasi pancang masing-masing area unit kerja diperoleh produktifitas alat HSPD sebagai berikut : 
a. Untuk alat HSPD 320 Ton, diperoleh rata-rata kecepatan waktu pemancangan sebesar $0,95 \mathrm{~m} / \mathrm{menit}$.

b. Untuk alat HSPD 420 Ton, didapat hasil rata-rata kecepatan waktu pemancangan sebesar $1,32 \mathrm{~m} /$ menit.

Sehingga dari perbandingan hasil berdasarkan waktu pemancangan disimpulkan bahwa alat HSPD 420 Ton kemampuan pemancangannya lebih cepat $\mathbf{0 , 3 7} \mathbf{~ m} / \mathbf{m e n i t}$ dari pada alat HSPD kapasitas 320 Ton.

2. Berdasarkan biaya pemancangan tiap titik lokasi pancang masing-masing area unit kerja diperoleh produktifitas alat HSPD sebagai berikut :

a. Biaya sewa alat HSPD

Biaya sewa alat HSPD dengan kapasitas 320 ton dan 420 ton diakumulasikan pembayarannya termasuk (include) ke dalam biaya-biaya operasional berikut ini :

1) Biaya Mobilisasi dan Demobilisasi

a) Alat HSPD 320 Ton

Biaya mobilisasi dan demobilisasi alat HSPD 320 Ton yang dibawa dari Medan tujuan Jambi sebesar Rp.350.000.000,-.

Sehingga biaya mobilisasi dan demobilisasi yang dikeluarkan untuk 1 titik lokasi tiang pancang dari total seluruh lokasi titik pancang di unit 1 sebanyak 157 titik adalah :

$$
\text { Biaya per titik }=\frac{\text { Rp.350.000.000,- }}{157 \text { titik }}=\text { Rp. 2.229.299,36/titik }
$$

b) HSPD 420 Ton

Biaya mobilisasi dan demobilisasi alat HSPD 420 Ton yang dibawa dari Medan tujuan Jambi sebesar Rp.400.000.000,-.

Sehingga biaya mobilisasi dan demobilisasi yang dikeluarkan untuk 1 titik lokasi tiang pancang dari total seluruh lokasi titik pancang di unit 2 sebanyak 182 titik adalah :

$$
\text { Biaya per titik }=\frac{\mathrm{Rp} \cdot 400 \cdot 000 \cdot 000,-}{182 \text { titik }}=\mathrm{Rp} \cdot 2 \cdot 197.802,20 / \mathrm{titik}
$$

2) Upah Pemancangan Tiang Pancang (handling spun pile)

Upah pemancangan tiang pancang (handling spun pile) adalah Rp.390.000,- untuk 2 kali join dengan alat HSPD 320 Ton dan/atau alat HSPD 420 Ton.

3) Upah Penyambungan/Pengelasan dan Pemotongan Tiang Pancang (joint dan welding)

Biaya penyambungan dan pengelasan tiang pancang (joint and welding) adalah Rp.120.000,-/meter tiang yang ditanam untuk HSPD 320 Ton dan HSPD 420 Ton.

b. Biaya Bahan Bakar Minyak (BBM)

Bahan Bakar Minyak (BBM) yang digunakan alat Generator Set (Genset) pada HSPD adalah jenis solar, dimana data yang Penulis dapat dilapangan bahwa penggunaan solar untuk satu hari kerja (8 jam) :

1) Alat HSPD 320 Ton

Alat ini menghabiskan 180 liter/hari dan biaya yang dikeluarkan sebesar Rp.2.340.000,- per hari waktu kerja 8 jam. Jadi selama 38 hari kerja pemancangan di unit 1 menghabiskan total Biaya BBM sebesar Rp.88.920.000,00.

2) Alat HSPD 420 Ton

Alat ini menghabiskan 200 liter/hari dan biaya yang dikeluarkan sebesar Rp.2.600.000,- per hari waktu kerja 8 jam. Jadi selama 49 hari kerja pemancangan di unit 2 menghabiskan total Biaya BBM sebesar Rp.127.400.000,00. 
Dari hasil perhitungan diatas, untuk biaya pengeluaran pemancangan pada titik lokasi pancang masing-masing area unit kerja diperoleh produktifitas alat HSPD sebagai berikut :

a. Untuk alat HSPD 320 Ton, jumlah biaya pengeluarannya sebesar Rp.891.310.000,00.

b. Untuk alat HSPD 420 Ton, jumlah biaya pengeluarannya sebesar Rp.1.286.659.890,11.

Sehingga berdasarkan biaya pengeluaran pemancangan disimpulkan bahwa alat HSPD 320

Ton biaya yang dikeluarkan selama pemancangan lebih kecil Rp.395.349.890,11 dari pada alat HSPD kapasitas 420 Ton.

Berdasarkan hasil perhitungan produktifitas Alat HSPD ditinjau dari waktu pemancangan dan biaya yang dikeluarkan, maka Penulis mengambil kesimpulan bahwa Alat HSPD kapasitas 320 ton lebih efektif dan efisien digunakan dalam kegiatan ini.

\section{Analisa SWOT (Strenght, Weakness, Opportunity, Threat) untuk Alat HSPD}

Dari uraian perhitungan dan penjelasan pada sub-sub bab sebelumnya, maka Penulis menganalisa efektifitas pemancangan dengan alat Hydraulic Static Pile Driver (HSPD) yang digunakan pada 2 area unit kerja dengan kapasitas 320 Ton dan 420 Ton adalah sebagai berikut:

1. Kekuatan (Strenght)

a. Alat HSPD Kapasitas 320 Ton

1) Mobilisasi alat ini lebih murah;

2) Biaya bahan bakar alat ini lebih murah karena kapasitas penggunaan listrik (power capacity) lebih kecil yaitu $150 \mathrm{KvA}$;

3) Manuver alat lebih gesit dari titik pancang yang satu ke titik pancang yang lain;

b. Alat HSPD Kapasitas 420 Ton

1) Beban maksimal ultimate yang dikeluarkan sampai pada kapasitas 420 ton;

2) Pada proses pemancangan, waktu penggunaan alat ini lebih cepat;

3) Mampu diaplikasikan pada tempat yang rapat dengan jarak $150 \mathrm{~cm}$ dari dinding bangunan eksisting, dikarenakan alat ini memiliki penyepit tiang pancang (clamping box) dibelakang alat;

2. Kelemahan (Weakness)

a. Alat HSPD Kapasitas 320 Ton

1) Kapasitas beban ultimatenya maksimal hanya sampai 320 ton.

2) Tidak mampu diaplikasikan pada tempat yang sempit dengan jarak $150 \mathrm{~cm}$ dari dinding bangunan eksisting, dikarenakan alat ini tidak memiliki penyepit tiang pancang (clamping box) dibelakang alat;

b. Alat HSPD Kapasitas 420 Ton

1) Mobilisasi alat ini lebih mahal, dikarenakan beban ultimate yang lebih besar sehingga membutuhkan alat angkut yang lebih banyak jumlahnya;

2) Biaya bahan bakar alat ini lebih mahal dikarenakan kapasitas penggunaan listrik (power capacity) yang cukup besar yaitu $175 \mathrm{KvA}$;

3. Peluang (Opportunity)

a. Alat HSPD Kapasitas 320 Ton

1) Mobilisasi yang lebih murah.

2) Biaya konsumsi BBM yang lebih kecil.

3) Segmen pasar kebutuhan akan alat HSPD jelas.

b. Alat HSPD Kapasitas 420 Ton

1) Proses pelaksanaan pemancangan yang lebih cepat.

2) Beban ultimate maksimal bisa mencapai 420 ton.

3) Bisa diaplikasikan untuk area yang rapat dengan jarak $150 \mathrm{~cm}$ dari sudut bangunan eksisting, karena memiliki penjepit tiang dibelakang alat. 
4) Segmen pasar kebutuhan akan alat HSPD jelas.

4. Ancaman/hambatan (Threat)

a. Alat HSPD Kapasitas 320 Ton

1) Tidak bisa bekerja di elevasi tanah yang lebih tinggi atau lebih rendah dari alat tersebut karena alat ini bekerja di tanah yang datar/rata, solusinya adalah menggunakan alat lain seperti bor pile.

2) Tidak bisa diaplikasikan untuk proyek-proyek pemancangan tiang jembatan khususnya yang bekerja diatas air.

3) Alat HSPD dengan kapasitas yang lebih kecil untuk pemancangan dilokasi yang sempit.

4) Perusahaan jasa sewa alat HSPD sejenis maupun alat pancang jenis lainnya yang menjadi pesaing dibidang konstruksi pemancangan.

5) Harga bahan bakar minyak (BBM) jenis solar untuk industri yang selalu naik.

b. Alat HSPD Kapasitas 420 Ton

1) Sama halnya dengan HSPD 320 Ton, alat ini tidak bisa bekerja di elevasi tanah yang lebih tinggi atau lebih rendah dari alat tersebut karena alat ini bekerja di tanah yang datar/rata, solusinya adalah menggunakan alat lain seperti bor pile.

2) Sama halnya dengan HSPD 320 Ton, alat ini juga tidak bisa diaplikasikan untuk proyek-proyek pemancangan tiang jembatan.

3) Alat HSPD dengan kapasitas yang lebih kecil untuk pemancangan dilokasi yang sempit.

4) Perusahaan jasa sewa alat HSPD sejenis maupun alat pancang jenis lainnya yang menjadi pesaing dibidang konstruksi pemancangan.

5) Harga bahan bakar minyak (BBM) jenis solar untuk industri yang selalu naik.

\section{DAFTAR PUSTAKA}

Bowles, Joseph E., 1991, Analisis dan Desain Pondasi, Edisi Keempat, Jilid 1, Penerbit PT. Erlangga, Jakarta.

Dokumen Kick of Meeting, 2018, Proyek Perluasan Terminal Bandara Sultan Thaha Jambi, PT. Jaya Konstruksi Manggala Pratama Tbk.

Hardiyatmo, Hary Christady, 1996, Teknik Pondasi I, Penerbit PT. Gramedia Pustaka Utama, Jakarta.

Hardiyatmo, Hary Christady, 1996, Analisis dan Perancangan Fondasi, Bagian II, Penerbit Gajah Mada University Press, Yogyakarta.

HS, Sardjono, 1988, Pondasi Tiang Pancang untuk Universitas dan Umum Jilid 1, Penerbit Sinar Wijaya, Surabaya.

HS., Mas Suryanto. dan Hadil, Brian Widyan, 2018, Analisis Produktivitas Pemancangan Dengan Alat Jack-In Pile jenis Hydrolic Static Pile Driver Pada Proyek Apartemen Graha Golf Surabaya, Universitas Negeri Surabaya, Surabaya.

HS, Sardjono, 1988, Pondasi Tiang Pancang untuk Universitas dan Umum Jilid 2, Penerbit Sinar Wijaya, Surabaya.

http://www.pengertianku.net/2015/03/pengertian-analisis-swot-dan-manfaatnya.html

(diakses pada tanggal 12 Agustus 2018 pukul 22.00 Wib)

Ismail, Suryani, 2006, Pondasi Cakar Ayam Menjabarkan Teori Prof. Sedijatmo, Penerbit PT. Perca, Jakarta.

Jawat, I Wayan, 2016, Metode Pelaksanaan Pekerjaan Tiang Pancang Sistem Hidraulic Jack In (Studi : Proyek KCU BCA Sunset Road Bali), Universitas Warmadewa, Bali.

Limanto, Sentosa, 2009, Analisis Produktivitas Pemancangan Tiang Pancang Pada Bangunan Tinggi Apartemen, Universitas Kristen Petra, Surabaya. 
Lubis, SM. Hari dan Huseini, Martani, 1987, Teori Organisasi : Suatu Pendekatan Makro, Pusat Antar Universitas Ilmu-ilmu Sosial, Jakarta.

Nurdiani, Nina, 2013, Pekerjaan Pondasi Tiang Pancang : Cara Pemancangan, Kendala dan Teknologi Terbaru, Binus University, Jakarta.

Pamungkas, Anugrah dan Harianti, Erny, 2013, Desain Pondasi Tahan Gempa, Penerbit PT. Andi, Yogyakarta.

Pasolong, Harbani, 2007, Teori Administrasi Publik, Penerbit Alfabeta, Jogyakarta.

Sosrodarsono, Suyono dan Nakazawa, Kazuto, 2000, Mekanika Tanah \& Teknik Pondasi, Penerbit PT. Pradnya Paramita, Jakarta.

Terzaghi, Karl dan Peck, Ralph B., 1987, Mekanika Tanah dalam Praktek Rekayasa, Edisi Kedua, Jilid 1, Penerbit PT. Erlangga, Jakarta.

www.rumahmaterial.com (komponen alat Hydraulic Static Pile Driver)

(diakses pada tanggal 07 Desember 2018 pukul $20.00 \mathrm{Wib}$ ) 